\title{
$>0$ devir-criança de Graciliano Ramos: uma leitura de Infância a partir de Deleuze
}

$>$ The becoming-child of Graciliano Ramos: a reading of Infância on Gilles Deleuze

\section{por Bruno Henrique Alvarenga Souza}

Doutorando em Letras: Estudos Literários na área de Teoria da Literatura e Literatura Comparada pela Universidade Federal de Minas Gerais (UFMG). Professor substituto da Universidade Federal de Ouro Preto (UFOP). Bolsista da Fundação de Amparo à Pesquisa de Minas Gerais (FAPEMIG). E-mail: alvarengabruno6@gmail.com. ORCID: 0000-00015005-1883

\section{Resumo}

Este artigo tem por objetivo realizar uma leitura do livro Infância, de Graciliano Ramos, a partir de conceitos cunhados pelo filósofo Gilles Deleuze. Desse modo, será discutida a escrita memorialista de Graciliano em confluência com a concepção deleuziana de impessoalidade na literatura, culminando na hipótese de que o escritor realiza em Infância, por meio de sua divisão entre menino-protagonista e adulto-narrador, aquilo que Deleuze chama de devir-criança.

Palavras-chave: Graciliano Ramos. Gilles Deleuze. Memória. Devir.

\begin{abstract}
This paper aims to read Graciliano Ramos's book Infância, based on concepts coined by the philosopher Gilles Deleuze. Thus, Graciliano's memorialist writing will be discussed in confluence with the Deleuzian conception of impersonality in the literature, culminating in the hypothesis that the writer realizes in Infância, through his splitting between boy-protagonist and adult-narrator, what Deleuze calls becoming-child.
\end{abstract}

Keywords: Graciliano Ramos. Gilles Deleuze. Memory. Becoming. 
Em Ficção e Confissão, Antonio Candido defende a tese de que, limitado pela ficção tradicional, Graciliano Ramos buscou na autobiografia sua última forma de expressão, "como consequência de uma marcha progressiva e irreversível, graças à qual o desejo básico de criação permanece íntegro, e a obra resultante é uma unidade solidária"1. O crítico observa em Graciliano uma tendência natural e necessária à memória, visualizando nessa passagem uma complementariedade fundamental à obra romanesca do autor:

\begin{abstract}
Depreende-se, pois, que as reminiscências não se justapõem à sua obra, nem constituem atividade complementar, como se dá na maior parte dos casos. Pertencem-lhe, fazem parte integrante dela, formando com os romances um só bloco, pois são essenciais para a compreensão da mesma ordem de sentimentos e ideias, dos mesmos processos literários que observamos neles. A autobiografia foi um caminho que escolheu e para o qual passou naturalmente, quando a ficção já não lhe bastava para exprimir-se. $^{2}$
\end{abstract}

Para Candido, os livros de memórias se integram aos romances, dando continuidade a uma mesma lógica, ampliando e problematizando as mesmas questões abordadas no estrato ficcional da obra. Infância e Memórias do cárcere evidenciam um método de rememoração que já aparecia nos romances de Graciliano: a recapitulação da vida por meio da escrita. Nos livros em primeira pessoa, os personagens-narradores são, em algum grau, escritores. João Valério, de Caetés, reconstitui seus dias com Luísa ao mesmo tempo em que elabora um romance-histórico; em S. Bernardo, a necessidade de lidar com o passado leva

\footnotetext{
${ }^{1}$ Antonio Candido, Ficção e Confissão, 2012, p. 97.

${ }^{2}$ Ibidem, p. 92.
} 
Paulo Honório, homem prático e indiferente à literatura, a se lançar à escrita de suas memórias; Luís da Silva, protagonista de Angústia, é um homem de letras fracassado que recapitula sua experiência e ordena seus pensamentos confusos em anotações particulares. Nesses três romances, os personagens são memorialistas. Em Infância e Memórias do cárcere, Graciliano reconfigura seu projeto literário, transformando-se em personagem das próprias memórias. Os personagens-autores dão lugar ao autor-personagem.

Graciliano uma vez afirmou: "nunca pude sair de mim mesmo. Só posso escrever o que sou" ${ }^{3}$. Baseando-se na experiência para elaborar sua literatura, dizia não possuir imaginação, censurando em colegas como Jorge Amado e José Lins do Rego o excesso de fantasia que leva ao irrealismo. Para Graciliano, há duas concepções de literatura que se opõem, e ele sabe muito bem a qual delas sua obra pertence.

A preocupação de Graciliano centraliza-se na oposição entre uma visão transfiguradora do material romanceável e outra fincada no solo concreto, resguardando a ficção dos voos da imaginação e atendo-se à transposição de uma experiência vivenciada. Obviamente, Graciliano defenderá a segunda postura. ${ }^{4}$

Graciliano insurge-se contra essas literaturas "imaginativas" por meio de uma escrita calcada na recriação de fatos. Em Memórias do cárcere, quando se

\footnotetext{
${ }^{3}$ Graciliano Ramos, citado por Homero Senna, República das letras: entrevistas com 20 grandes escritores brasileiros, 1996, p. 207.

${ }^{4}$ Marcelo Magalhães Bulhões, Literatura em campo minado: a metalinguagem em Graciliano Ramos e a tradição literária brasileira, 1999, p. 69-70.
} 
compara a José Lins do Rego e destaca a grande capacidade de invenção do colega pernambucano, salienta: “eu seria incapaz de semelhante proeza: só me abalanço a expor coisa observada e sentida" ${ }^{5}$. Mesmo nos romances, Graciliano prima pela escrita daquilo que conhece. É o que diz na célebre recomendação que faz à irmã que inicia na literatura: "só conseguimos deitar no papel os nossos sentimentos, nossa vida. Arte é sangue, é carne. Além disso não há nada. As nossas personagens são pedaços de nós mesmos, só podemos expor o que somos" ${ }^{\prime 6}$.

Como aproximar, como pretendemos neste artigo, essa literatura do pensamento de Gilles Deleuze, autor que afirma com frequência que não se deve fazer literatura da própria experiência, que não há grande artista ou escritor que fale de si mesmo, para quem "escrever não é contar as próprias lembranças, suas viagens, seus amores e lutos, sonhos e fantasmas"7? Em uma leitura superficial, essa concepção filosófica da criação literária se afasta da prática de escrita memorialística em Graciliano. Para o filósofo, a vivência singular de um indivíduo não interessa como obra artística, deve-se escrever o mundo e não a limitada cena privada de nossas próprias vidas. Mas o aparente apego de Graciliano à experiência vivida esconde uma concepção literária que não se restringe à observação crua do real. Na "poética" que abre as Memórias do cárcere, o escritor distingue a verossimilhança da verdade, pois "coisas verdadeiras podem não ser verossímeis"8, e esclarece seu procedimento:

\footnotetext{
${ }^{5}$ Graciliano Ramos, Memórias do Cárcere, 2011, p. 41.

${ }^{6}$ Idem, Cartas, 1994, p. 213.

${ }^{7}$ Gilles Deleuze, Crítica e Clínica, 2011, p. 12.

${ }^{8}$ Graciliano Ramos, Memórias do Cárcere, 2011, p. 13.
} 
Não me agarram métodos, nada me força a exames vagarosos. Por outro lado, não me obrigo a reduzir um panorama, sujeitá-lo a dimensões regulares, atender ao paginador e ao horário do passageiro do bonde. Posso andar para a direita e para a esquerda como um vagabundo, determe em longas paradas, saltar passagens desprovidas de interesse, passear, correr, voltar a lugares conhecidos. Omitirei acontecimentos essenciais ou mencioná-los-ei de relance, como se os enxergasse pelos vidros pequenos de um binóculo; ampliarei insignificâncias, repeti-las-ei até cansar, se isto me parecer conveniente. ${ }^{9}$

O escritor retrabalha, à sua maneira, a experiência que põe no papel e, em maior ou menor grau, modifica os fatos quando os transcreve para sua obra. Qualquer artista, seja qual for sua prática estética, cria uma realidade outra que atravessa o vivido ao mesmo tempo em que o condensa em sua obra, seja esta classificada como autobiográfica ou não.

Talvez a principal dificuldade da escrita memorialista seja determinar o lugar do eu que escreve. Como fugir do egocentrismo ao se escrever como autor personagem? Em sua obra, Graciliano tenta responder a essa pergunta se afastando do individualismo e indo em direção a uma abordagem política e impessoal. Para Graciliano, recorrer à experiência vivida não significa prenderse ao personalismo, pelo contrário, é em busca de uma memória coletiva que ele recorre à infância ou à temporada como prisioneiro do regime Vargas. É uma reescrita da realidade - não apenas sua representação - na qual o eu é um entrave:

Desgosta-me usar a primeira pessoa. Se se tratasse de ficção, bem: fala um sujeito mais ou menos imaginário; fora daí é desagradável adotar o pronomezinho irritante, embora se façam malabarismos por evitá-lo.

\footnotetext{
${ }^{9}$ Ibidem, p. 14.
} 
Desculpo-me alegando que ele me facilita a narração. Além disso não desejo ultrapassar o meu tamanho ordinário. Esgueirar-me-ei para os cantos obscuros, fugirei às discussões, esconder-me-ei prudente por detrás dos que merecessem patentear-se. ${ }^{10}$

É nesse momento que Graciliano se encontra com Deleuze, que afirma: "a literatura só começa quando nasce em nós uma terceira pessoa que nos destitui do poder de dizer Eu"11. Nos textos de Graciliano, a impessoalidade do ele(s) sobrepuja a identidade do "pronomezinho irritante" eu. O deslocamento do autor-personagem para a margem determina o projeto estético-político que nos parece ser central em sua obra: a escrita como voz do despossuído, como iluminação dos cantos obscuros da sociedade - a literatura, como diz Deleuze, por um povo que falta:

Graciliano, firme na sua disposição de ir contra a amnésia histórica e social, torna efetiva talvez como nenhum outro escritor entre nós, a possibilidade de uma prática política do texto artístico. Daí o papel fundamental desempenhado pela memória em seus livros. Operadora da diferença e trabalhando com pontos de esquecimento da história oficial, ela se formula como atividade produtiva, que tece com as ideias e imagens do presente a experiência do passado, sempre renovada, refeita, recriada vida e morte, vida contra a morte. ${ }^{12}$

Rememorar é um ato de criação onde o passado, reencontrado no presente, remete ao futuro. Sobre seus personagens, diz Graciliano: “Todos os meus tipos foram constituídos por observações apanhadas aqui e ali, durante

\footnotetext{
${ }^{10}$ Ibidem, p. 16.

${ }^{11}$ Gilles Deleuze, Crítica e Clínica, 2011, p. 13.

${ }^{12}$ Wander Melo Miranda, Graciliano Ramos, 2004, p. 11.
} 
muitos anos. É o que penso, mas talvez me engane. É possível que eles não sejam senão pedaços de mim mesmo e que o vagabundo, o coronel assassino, o funcionário e a cadela não existam"13. 0 escritor é ele mesmo vários, através de sua caneta ecoam infinitas vozes. A literatura atinge a potência coletiva quando o escritor se torna imperceptível, quando sua individualidade dá lugar a vozes que seriam inauditas de outra maneira, quando o pronome pessoal dá lugar ao artigo indefinido, em suma, quando se estabelece um agenciamento coletivo de enunciação.

Na obra de Graciliano, Infância dá início à guinada definitiva ao memorialismo que caracteriza os escritos tardios do escritor. Quando Antonio Candido propõe o movimento gradual de passagem da ficção à confissão, ele não deixa de notar, ao menos no que diz respeito a Infância, a fatura imaginativa que faz parte da escrita do passado:

Talvez seja errado dizer que Vidas Secas seja o último livro de fiç̧ão de Graciliano Ramos. Infância pode ser lido como tal, pois a sua fatura convém tanto à exposição da verdade quanto da vida imaginária; nele, as pessoas parecem personagens e o escritor se aproxima delas por meio da interpretação literária, situando-as como criações. ${ }^{14}$

Podemos compreender esse deslocamento proposto por Candido como um movimento desterritorializante da obra de Graciliano. O escritor abandona o território romanesco e reterritorializa-se na escrita memorialista. Obviamente, não há aí a exclusão do ficcional, mas uma reconfiguração do material literário,

\footnotetext{
${ }^{13}$ Graciliano Ramos, Linhas Tortas, 2002, p. 192.

${ }^{14}$ Antonio Candido, Op. Cit., p. 69.
} 
que passa a ser estruturado a partir da biografia. Os acontecimentos vivenciados pelo autor são reinterpretados por meio da linguagem, transmutam-se, tornamse criações.

No entanto, o lado ficcional das memórias de Graciliano durante muito tempo foi desconsiderado por parte da fortuna crítica do escritor. Gustavo Ribeiro demonstra como diversas leituras especializadas privilegiam o aspecto biográfico contido em Infância, inclusive tentando justificar a obra do escritor se utilizando dos episódios e personagens presentes no livro de memórias, apresentando-o como relato estritamente documental.

\begin{abstract}
Procurando apenas o substrato dos episódios e sensações reais vividas pelo autor, os estudos críticos [...] concentraram-se na busca e interpretação da vertente documental das memórias de Graciliano, deixando de lado, entre outras coisas, as reflexões que o narrador faz acerca da matéria narrada; assim também, por fim, é preciso concluir que esse conjunto de críticos não estudou com todo o detalhe possível, dadas as suas escolhas metodológicas, os recursos literários utilizados no texto para reelaboração escrita da vida que tem lugar em Infância. ${ }^{15}$
\end{abstract}

Toda narrativa é criação. Mesmo que retome determinada experiência vivida, a narrativa a remodela de tal forma que, ao invés de representá-la, acaba por criar outra de natureza completamente diferente. Todo refazer é fazer o/de novo. Deleuze e Guattari afirmam que todo e qualquer artista faz uso de uma "fabulação criadora [que] nada tem a ver com uma lembrança mesmo amplificada, nem com um fantasma"16 ${ }^{16}$ artista não cria, portanto, reproduzindo

\footnotetext{
${ }^{15}$ Gustavo Silveira Ribeiro, Abertura entre as nuvens, 2012, p. 42.

${ }^{16}$ Gilles Deleuze e Félix Guattari, O que é a Filosofia?, 2010, p. 201.
} 
uma experiência do passado, nem mesmo tentando transcrever uma vivência presente: ele almeja sempre algo além do pessoal, algo além de seu próprio tempo. O que o artista vislumbra é o futuro: ele "é um vidente, alguém que se torna [devém]"17. Longe de ser por intermédio de uma repetição do Mesmo, de uma busca pelo passado a ser capturado na escrita, é por meio do eterno retorno da diferença que o escritor encontra o cerne de seu fazer. Obviamente, o vivido pode servir de objeto e ferramenta para tal espécie de visionário, afinal, o passado retorna; mas o produto resultante do trabalho do escritor, o diferente que emerge da linguagem, é criação que ultrapassa qualquer biografia. É próprio da arte dizer respeito antes ao coletivo que ao indivíduo. O puro relato de uma experiência pessoal não é capaz de atingir a polissemia inerente à arte. Se reduzimos a vida a nossas histórias particulares, enquadrando-a em uma narrativa linear de início, meio e fim; ou se a suspendemos no tempo, remetendo tudo a uma origem, a um eterno teatro representado sempre pelos mesmos papéis, isso nada tem a ver com a potência que a arte capta da Vida. Se a vida particular, com nossas neuroses, fantasmas e vivências, é registrada, contabilizada e valorada de acordo com o tempo de Cronos, isto é, o tempo cronológico, físico, que pode ser medido, a vida da arte existe em um tempo que não pode ser reduzido a passado, presente e futuro, ela pertence ao tempo de Aion, tempo cíclico, imensurável e eterno. É o que quer dizer Deleuze quando afirma: “a escrita é uma passagem de vida que atravessa o vivível e o vivido"18.

Em Infância, Graciliano complexifica a relação passado/presente/futuro utilizando uma narrativa que joga com os tempos do enunciado e da enunciação,

\footnotetext{
${ }^{17}$ Ibidem, p. 203.

${ }^{18}$ Gilles Deleuze, Crítica e Clínica, 2011, p. 11.
} 
dando a eles vozes que conversam, distinguem-se e se confundem na mesma medida. Fabulação e tempo convergem na produção da escrita. Escrever é hábito, memória e retorno da diferença; é presente, passado e futuro. Graciliano afirma a respeito dos acontecimentos que relata em Infância: "e nem deles posso afirmar que efetivamente me recorde. O hábito me leva a criar ambientes, imaginar fatos a que atribuo realidade"19. Quando afirma ser o hábito que o leva à fabulação, o escritor naturalmente se refere ao hábito de escrever, ao ofício de literato. $\mathrm{O}$ ato da escrita se dá no presente, constituindo, ao mesmo tempo em que se dá, o próprio sujeito que escreve. $\mathrm{O}$ ato presente de escrever é paradoxalmente passivo: ele não se torna ativo até que busque no outro mundo do passado sua matériaprima. É o passado que fundamenta o escritor: embora seja este quem funde a escrita no presente, é a memória que possibilita o hábito de escrever. Mas a memória é múltipla e configurada a partir da conexão escritor/mundo estabelecida no presente do hábito. Portanto, quando se escreve, presente e passado, hábito e memória, conjugam-se, criando novas realidades que, no contexto literário, podemos chamar de realidades-ficções. É o que percebemos no processo fabulador de Graciliano, ressaltado nos capítulos de abertura de Infância, já apontados pela crítica como espécie de síntese do livro e do procedimento memorialístico do escritor:

Os três primeiros capítulos são pedaços dos capítulos subsequentes vasos, miniaturas que, emparelhados, dão forma a um vaso maior: o livro de Graciliano Ramos. Os vasos menores - os capítulos iniciais -

\footnotetext{
${ }^{19}$ Graciliano Ramos, Infância, 2002, p. 23.
} 
estilhaçam-se num emaranhado de fatos, pessoas, objetos de lembranças, sintetizando Infância e a poética memorialística de Graciliano. ${ }^{20}$

O capítulo de abertura, "Nuvens", é arquitetado em torno da imprecisão da memória e sua atuação deformadora do passado. O que resta de objetos remotos, recriados na imaginação, é uma espécie de cópia malfeita ou, remetendo aqui a Deleuze, um simulacro: "não conservo a lembrança de uma alfaia esquisita, mas a reprodução dela, corroborada por indivíduos que lhe fixaram o conteúdo e a forma" ${ }^{21}$. A memória, além de reproduzir de maneira duvidosa as imagens que se lhe fixam, é cheia de lacunas, espaços vazios preenchidos por soluções de continuidade: pessoas, lugares, situações "aparecem hoje como rasgões num tecido negro"22. $\mathrm{O}$ uso do advérbio hoje enfatiza o caráter reflexivo da memória e situa no tempo um narrador que se volta para o passado a partir do presente. No entanto, fica claro ao longo do livro que essas demarcações de tempo dão conta de uma temporalidade bem mais intrincada do que seria a de um mero olhar revisionista sobre os fatos vivenciados na infância. O que destaca Wander Melo Miranda a respeito do uso dos advérbios antes e agora nas Memórias do cárcere se mostra também em Infância e de forma ainda mais complexa:

No antes que emerge no presente da escrita como um agora retroativo, afirma-se tanto a dualidade inerente ao registro temporal, quanto a da voz narrativa que, em razão da referida postura do narrador frente ao narrado, entrelaça o Graciliano personagem dos fatos vivenciados ao Graciliano encarregado de narrá-los. A distinção entre passado e presente, interno e

\footnotetext{
${ }^{20}$ Maria de Lourdes Oliveira, Cacos da memória: uma leitura de "Infância", de Graciliano Ramos, 1992, p. 42.

${ }^{21}$ Graciliano Ramos, Infância, 2002, p. 7.

${ }^{22}$ Ibidem, p. 9.
} 
externo, que remete à relação entre o modelo empírico e sua encenação autobiográfica, não se coloca em termos opositivos rígidos e excludentes. ${ }^{23}$

Essas impressões vacilantes e obscurecidas do passado prosseguem no capítulo "Manhã", embora aqui o narrador já seja capaz de ajuntar algumas referências concretas, mesmo que confusas e cambiantes:

Naquele tempo a escuridão se ia dissipando, vagarosa. Acordei, reuni pedaços de pessoas e de coisas, pedaços de mim mesmo que boiavam no passado confuso, articulei tudo, criei o meu pequeno mundo incongruente. Às vezes as peças se deslocavam - e surgiam estranhas mudanças. Os objetos se tornavam irreconhecíveis, e a humanidade, feita de indivíduos que me atormentavam e indivíduos que não me atormentavam, perdia os característicos. ${ }^{24}$

A memória do narrador que se lembra no presente se confunde com a memória do menino que viveu o passado. O primeiro recorda o que o segundo não lembrava, vai preenchendo lacunas inapreensíveis pela criança nos tempos da infância. Se a inconstância é tanto das coisas quanto das pessoas, o narrador remonta cenários e tipos, buscando compreender o que o menino não compreendia. Assim, fala dos pais, compara seu ofício de escritor ao artesanato de urupemas do avô, revisita e reconstrói a antiga fazenda da família. Mas essa reescrita da vida não se potencializaria se continuasse num ciclo individual e melancólico, onde o sujeito se vê repartido entre os objetos atuais do presente e os objetos virtuais do passado, tentando, por meio da memória, uma espécie de salvação de sua própria ausência de fundamento. Apegado à memória, o homem

\footnotetext{
${ }^{23}$ Wander Melo Miranda, Corpos escritos, 2009, p. 122.

${ }^{24}$ Graciliano Ramos, Infância, 2002, p. 17.
} 
que apenas lembra permanece preso ao gozo de um passado distante e à melancolia de um presente incapturável.

No capítulo "Verão", passamos a compreender mais precisamente o funcionamento do processo fabulador-memorialístico de Graciliano. Nele, "torna-se evidente como, para o autor, não interessa o mero registro ou transposição fotográfica da realidade externa, mas a sua (re)construção através dos mecanismos conjugados da imaginação e da memória" ${ }^{25}$. A reconstrução do cenário de seca lancinante perpassa as lembranças mais vagas, mas se efetiva apenas mediante a captação de imagens primordiais, mais criadas que necessariamente vividas.

\begin{abstract}
Desse antigo verão que me alterou a vida restam ligeiros traços apenas. $\mathrm{E}$ nem deles posso afirmar que efetivamente me recorde. [...] Sem dúvida as árvores se despojaram e enegreceram, o açude estancou, as porteiras dos currais se abriram, inúteis. É sempre assim. Contudo ignoro se as plantas murchas e negras foram vistas nessa época ou em secas posteriores, e guardo na memória um açude cheio, coberto de aves brancas e de flores [...]. Certas coisas existem por derivação e associação; repetem-se, impõem-se - e, em letra de fôrma, tomam consistência, ganham raízes. Dificilmente pintaríamos um verão nordestino em que os ramos não estivessem pretos e as cacimbas vazias. Reunimos elementos considerados indispensáveis, jogamos com eles, e se desprezamos alguns, o quadro parece incompleto. ${ }^{26}$
\end{abstract}

As coisas que se repetem e se impõem são aquilo que é selecionado pelo eterno retorno, o que retorna porque possui a força necessária para fazê-lo. Apontam para o futuro mais do que remetem ao passado, integram processos de

\footnotetext{
${ }^{25}$ Wander Melo Miranda, Corpos escritos, 2009, p. 45.

${ }^{26}$ Graciliano Ramos, Infância, 2002, p. 23.
} 
diferenciação mais do que de semelhança: são devires, desterritorializações. Deleuze e Guattari conceituam tais elementos como blocos de sensações: "pintamos, esculpimos, compomos, escrevemos com sensações. Pintamos, esculpimos, compomos, escrevemos sensações"27. As sensações são a própria matéria-prima da qual a arte é feita. "A arte conserva, e é a única coisa no mundo que se conserva"28. Ela conserva o sorriso de uma moça na tela pintada, a paisagem descrita num romance, mas também conserva a si mesma. Embora, de fato, só perdure enquanto resistem seus materiais, a tinta, o papel etc., a arte, no breve instante em que existe, já alcança a eternidade. A conservação da arte não é do tipo industrial, que acrescenta uma substância que faz perdurar a coisa; a arte existe em si, é pura sensação e "não é dependente do espectador ou do auditor atuais, que se limitam a experimentá-la, num segundo momento, se têm força suficiente. E o criador então? Ela é independente do criador pela autoposição, que se conserva em si" ${ }^{29}$. Portanto, nas páginas de "Verão", está conservada a seca nordestina. Graciliano persegue a sensação dessa seca que ele conheceu quando menino, mas o fruto artístico que daí resulta de nenhuma maneira é semelhante à experiência da infância. Os blocos de sensações são compostos por perceptos e afectos. Perceptos não são percepções, porque não dependem do estado daquele que os experimenta. Afectos não são afetos pelo mesmo motivo. Desse modo, os perceptos e afectos que compõem a sensação são válidos em si mesmos e estão além de qualquer vivido. O objetivo da arte para Deleuze e Guattari é retirar o percepto das percepções, os afectos dos afetos: dar a criação vida própria, uma autossuficiência que, mesmo com o esfacelamento da

\footnotetext{
${ }^{27}$ Gilles Deleuze e Félix Guattari, O que é a Filosofia?, 2010, p.196.

${ }^{28}$ Ibidem, p. 193.

${ }^{29}$ Ibidem, p. 193.
} 
matéria, seja eterna, ainda que dure apenas um instante. Graciliano não rememora os fatos de sua infância, ele faz deles um retrato do infinito - seus olhos de homem transformam-se novamente em olhos de menino e, em meio à experiência e à linguagem de homem maduro, são as sensações da criança que permeiam as páginas. Perceptos arrancados de percepções vividas, que capturam os tempos de seca na sensação de "uma longa noite, um dia imenso e enervante, favorável à modorra. Frio e calor, trevas densas e claridades ofuscantes" ${ }^{30}$; afectos abstraídos de afecções, que, diante da falta d'agua, deixam "a boca enxuta, os beiços gretados, os olhos turvos, queimaduras interiores" ${ }^{31}$. $\mathrm{O}$ calor, a sede, a modorra, a morte: sensações, perceptos e afectos. Tais sensações provêm da vivência do escritor, mas superam-na, tornam-se uma experiência por si só. Uma vida que, exposta na linguagem, extrapola qualquer limite do vivível. Por isso, a busca de qualquer fonte biográfica torna-se irrelevante, porque o que se vislumbra na arte é o tempo futuro. $O$ eterno retorno da diferença se dá na escrita na medida em que o passado que retorna por meio da memória traz consigo elementos sempre novos.

O bloco de sensações criado por Graciliano, seus perceptos e afectos, abrese em múltiplos caminhos, em infinitas linhas emaranhadas. O principal veículo dessas sensações é o devir. Escrever é devir. É devir algo além de homem, além de escritor: é devir-animal, devir-criança, devir-mulher, até mesmo devirimperceptível. Em Infância, interessa-nos um devir em específico: o devircriança. Para compreendê-lo, devemos, como já afirmamos reiteradamente, afastar-nos do biografismo estrito que tenta explicar a obra a partir da vida do

\footnotetext{
${ }^{30}$ Graciliano Ramos, Infância, 2002, p. 17.

${ }^{31}$ Ibidem, p. 24.
} 
autor, ou se utiliza do texto para iluminar posições pessoais daquele que escreve. Boa parte da fortuna crítica sobre o escritor alagoano recai nessa velha armadilha. Ainda que adotando posições diversas, ela parece ainda presa às vicissitudes do indivíduo e do particular. Isso pode ser ilustrado a partir das leituras que alguns desses críticos fazem das descrições duras e desprovidas de sentimentalismo de Infância, vendo nelas um ato de vingança de Graciliano contra os entes de seu passado, em vista das penúrias pelas quais o escritor passou. Nessa linha, Álvaro Lins escreve:

Porque não se sentiu amado, nem teve uma infância de ternuras e afagos, o Sr. Graciliano Ramos reagiu com sentimentos de indiferença e desprezo em face de toda a humanidade. Ele não escreveu essas memórias apenas por motivos literários, antes para se libertar dessas lembranças opressivas e torturantes. Escreveu a história de sua infância porque a detesta com amargura. Não se achou, por isso, obrigado a complacências para com os outros. $^{32}$

Outros críticos, como Gustavo Silveira Ribeiro, postulam que Graciliano recria o passado com a intenção de fazer um trajeto de reflexão e busca da compreensão do outro. A ficcionalização da infância serviria para que o autor justificasse para si os atos alheios, tendo em vista entendê-los e mesmo perdoálos. ${ }^{33}$ Também essa perspectiva amarra Graciliano a si mesmo, reduzindo-o à sua própria individualidade, encarcerando-o novamente em um biografismo implícito. Pois, se ele recria o passado não para se vingar, mas para perdoar, isso ainda significa se fixar ao pronome pessoal, ao eu. Pretendemos demonstrar que,

\footnotetext{
${ }^{32}$ Álvaro Lins, Valores e Misérias de Vidas Secas, 2002, p. 141.

${ }^{33}$ Cf. Gustavo Silveira Ribeiro, Abertura entre as nuvens, 2012.
} 
em suas memórias, Graciliano erige uma terceira pessoa que elimina a identidade e a personalização da escrita por meio de devires.

O que é devir? Devir não é imitar, não é 'fazer-se de'; devir é “encontrar a zona de vizinhança, de indiscernibilidade ou de indiferenciação tal que já não seja possível distinguir-se de uma mulher, de um animal, ou de uma molécula" ${ }^{34}$. Para devir-criança ou devir-animal não basta, então, fingir-se criança ou escrever como criança: é preciso ser essa criança, apagar a fronteira que afasta o homem de sua infância. Devir é processo, movimento, pressupõe o inacabado. Sempre se devém em oposição. Não existe um devir-homem, já que o homem-europeubranco é por si só um padrão maior. Devir é produzir movimentos moleculares em estruturas molares, tornar-se menor em relação ao registro maior. Os devires de Graciliano levam-no a atingir a enunciação coletiva que dá à sua escrita dimensão política. Para devir-criança, o autor deve ficcionalizar. Assim, sobre Graciliano, afirma Ribeiro que "ao decidir narrar as suas lembranças de criança, já homem maduro e escritor consagrado, o autor se viu diante da dificuldade de recriar o olhar infantil que um dia foi o seu. Como, de resto, esse olhar é irrecuperável na sua integridade, Graciliano tratou de inventá-lo"35. Portanto, não são simples lembranças de infância que compõem o livro de Graciliano e sim blocos de infância compostos de perceptos e afectos ficcionais. Mas onde enxergamos devires, a crítica muitas vezes viu personalismo, biografia explícita. É partir da desconstrução da ideia tradicional de narrador, que a principal

\footnotetext{
${ }^{34}$ Gilles Deleuze, Crítica e Clínica, 2011, p. 11.

${ }^{35}$ Gustavo Silveira Ribeiro, Abertura entre as nuvens, 2012, p. 53.
} 
potência política e coletiva de Graciliano Ramos em Infância, o devir-criança, acontece.

A questão das vozes que se alternam na narrativa das memórias também já foi estudada várias vezes pela crítica. São elas: a voz do adulto-narrador no tempo da enunciação e a voz do menino-personagem, sujeito do enunciado. $\mathrm{O}$ primeiro, situado no presente, é o homem que analisa e reflete as ações e impressões que o segundo vivencia. Por exemplo, em um trecho do capítulo "Verão", o olhar do menino-protagonista, acerca da seca que assolava o pai e a família, é o seguinte:

as nascentes secavam, o gado se finava no carrapato e na morrinha. Estranhei a morrinha e estranhei o carrapato, forças evidentemente maiores que as de meu pai. [...] Explicavam a sisudez, o desgosto habitual, as rugas, as explosões de pragas e as injúrias. ${ }^{36}$

Dando seguimento direto à passagem, o adulto-narrador, então no tempo presente, comenta:

Hoje acho naturais as violências que o cegavam. Se ele estivesse embaixo, livre de ambições, ou em cima, na prosperidade, eu e o moleque José teríamos vivido em sossego. Mas no meio, receando cair, avançando a custo, perseguido pelo verão, arruinado pela epizootia, indeciso, obediente ao chefe político, à justiça e ao fisco, precisava desabafar, soltar a zanga concentrada. ${ }^{37}$

\footnotetext{
${ }^{36}$ Graciliano Ramos, Infância, 2002, p. 26.

${ }^{37}$ Ibidem, p. 26-7.
} 
A voz do menino-protagonista, característica do passado, representa o ponto de vista da criança sobre os acontecimentos, pessoas e lugares pretéritos, caracterizando-se pelo espanto e pela fragilidade que ela sente em sua relação com o mundo. Já o adulto-narrador, estabelecido no presente, mediador do passado, é dono de uma visão analítica e crítica das experiências do menino, situadas no tempo dos acontecimentos. Em vários momentos, tais vozes se misturam, constituindo um novo tipo de narrador que, voltando-se para o passado e escrevendo no presente, vislumbra o futuro. Exemplos dessa complexidade narrativa são os capítulos gêmeos, "Chegada à vila" e "A vila", que relatam a mudança da família Ramos do campo para a cidade. O primeiro é focado nas impressões do menino-personagem; o segundo, nas reflexões do adulto-narrador. "Ambos apresentam o mesmo ambiente e as mesmas pessoas, mas entre os textos há pouca ou nenhuma semelhança, formal ou mesmo de conteúdo"38. Em "Chegada à vila", o texto transparece a sensação de estranhamento e fascínio do menino em vista das novidades que a mudança da família lhe apresenta. Graciliano busca captar esse espanto através do olhar fragmentado do menino-protagonista, utilizando como técnica narrativa uma enumeração quase caótica de pedaços da realidade. O que o menino enxerga são estilhaços: de pessoas, de animais, de construções. Já em "A vila", a perspectiva muda. É a reflexão crítica do adulto-escritor-narrador que dá o tom das descrições, aqui mais voltadas para uma visão de conjunto do que calcadas nos detalhes. O maravilhamento do menino é substituído pela rígida análise do adulto, que delineia de maneira abrangente e acurada a geografia, os hábitos, e mesmo o caráter da vila de Buíque. Depois de situar a disposição espacial do

${ }^{38}$ Gustavo Silveira Ribeiro, Abertura entre as nuvens, 2012, p. 66. 
lugar, que com suas cinco ruas "tinha a aparência de um corpo aleijado" ${ }^{39}$, Graciliano faz uma apresentação sumária dos moradores da vila. Dentre esses personagens, destacam-se seu Afro e d. Maroca, pessoas vistas com desprezo pelo resto da população por não se enquadrarem em seus padrões de moralidade. Eles levam o narrador à autorreflexão característica dos relatos no tempo da enunciação:

Espantaram-me a desconsideração e a frieza que envolviam essas criaturas [...]. Contudo esse julgamento absurdo acompanhou-me. Indigno-me, quero extirpá-lo, reabilitar seu Afro e D. Maroca. Duas pessoas normais. Penso assim. E desprezo-as, sinto-as decaídas. Impossível deixar de sentílas decaídas. Repito mentalmente os desconchavos de Padre João Inácio. ${ }^{40}$

São essas reflexões morais características do adulto-narrador que levaram a crítica, de modo geral, à repartição entre vingança e perdão que destacamos anteriormente. Para ambas as visões, o papel do narrador é semelhante. Do ponto de vista dos que veem Infância como memórias de ressentimento, a cisão dos tempos narrativos entre a criança e o adulto serve para punir aqueles que foram responsáveis pelas desgraças na infância do escritor, por meio de caracterizações animalescas dos personagens observados pelo menino-protagonista ou reflexões amargas do adulto-narrador. Já do lado dos que leem Infância como obra do perdão e do esquecimento, a divisão de vozes teria como objetivo proporcionar sobre os fatos um olhar revisionista e ético, de um adulto que procura encontrar

\footnotetext{
${ }^{39}$ Graciliano Ramos, Infância, 2002, p. 45.

${ }^{40}$ Ibidem, p. 51.
} 
sentido nos atos pretéritos tanto da criança que ele foi quanto dos adultos que o cercavam.

Propomos uma maneira diferente de compreender essas vozes. O narrador duplo não é um ser cindido pelo tempo, dividido entre criança e adulto, entre passado e presente. Se fosse assim, estaria ainda preso ao círculo melancólico de Eros, buscando no passado um fundamento para seu ser. Em acordo com as sínteses temporais elaboradas por Deleuze podemos fazer a seguinte associação: menino, passado, memória; adulto, presente, hábito; devir-criança, futuro, eterno retorno do diferente. Enquanto o menino traz à tona o passado distante da infância através da memória, e o escritor adulto, no tempo presente, busca apreender esse passado por meio do hábito da escrita, o devir-criança funciona como a unificação dessa criança e desse adulto, do presente e do passado, existindo no porvir, na potência da virtualidade. Desse modo, Infância não é um retorno ao passado mediante sua reescrita no presente: o livro é a captação do Tempo mesmo, incluindo sua dimensão futura. Ao ler Em busca do tempo perdido, de Proust, Deleuze afirma que a memória é apenas um meio para um aprendizado, ferramenta utilizada para que o pensamento seja apresentado a signos que o forcem a funcionar. A arte possui a particularidade de transmutar os signos materiais em signos imateriais que permitem reencontrar a essência do tempo, ultrapassando a separação cronológica entre passado, presente e futuro. ${ }^{41}$ Assim como Proust, que ao final de sua obra, constata que a arte traz esse tempo que não é o tempo vivido, mas o tempo redescoberto, o tempo em si mesmo, Graciliano não recria seu passado, mas sim torna visível sua força invisível.

${ }^{41}$ Gilles Deleuze, Proust e os signos, 2010, p. 47-50. 
Assim, o narrador de Infância rompe a barreira entre o presente e o passado, e não apenas reflete sobre o já vivido, mas o revive no próprio hoje, vislumbrando o amanhã. Há uma intrínseca complexidade temporal que o leva a determinar o passado pelo presente e o presente pelo passado. Na verdade, eles são um só. Sujeito tanto do enunciado quanto da enunciação, o narrador de Infância é a terceira pessoa que destitui Graciliano de dizer eu. Essa terceira pessoa é o devircriança do autor, uma criança que "coexiste conosco, numa zona de vizinhança e ou num bloco de devir, numa linha de desterritorialização que nos arrasta a ambos [homem e criança] - contrariamente à criança que fomos, da qual nos lembramos ou que fantasmamos, a criança molar da qual o adulto é o futuro" ${ }^{42}$.

Em sua biografia sobre Graciliano, "Um homem bruto da terra", Valentim Facioli associa o pavor gerado pela educação nordestina descrita em Infância com a vivência também traumatizante no regime do Estado Novo. ${ }^{43} \mathrm{~A}$ tarefa de escrever Infância se impõe antes da tarefa de escrever sobre a experiência da prisão, mas isso acontece pela necessidade do escritor de remontar um passado que o faça compreender o presente, e que também lance luz ao futuro. Retomar a "bárbara educação nordestina" 44 é uma forma de resistir à também bárbara e arbitrária ditadura varguista. Portanto, devir criança não é retornar ao passado infantil, mas sim encontrar a infância na própria idade em que se está. Trata-se de uma involução criadora. Graciliano não é uma criança quando escreve Infância e nem mesmo tenta, por meio da memória, reencontrar a criança que foi. Devir é sempre um processo molecular: “a moça e a criança não devém, é o

\footnotetext{
${ }^{42}$ Gilles Deleuze e Félix Guattari, Mil Platôs, vol. 2, 2012, p. 67.

${ }^{43}$ José Garbuglio, Alfredo Bosi e Valentim Facioli, Antologia e Estudos: Graciliano Ramos, 1987, p. 25.

${ }^{44}$ Graciliano Ramos, Memórias do Cárcere, 2011, p. 538.
} 
próprio devir que é criança ou moça" ${ }^{45}$. Dessa maneira, o devir-criança que o toma é uma potência do próprio homem-adulto-escritor de 53 anos. A desterritorialização que esse devir acarreta o levará à infância, ao interior do Nordeste, ao aprendizado das letras; mas também o arrastará de volta ao presente, à vida adulta, à ebulição política presenciada de perto na prisão e na capital do país, ao fazer literário de escritor. Todo o livro Infância gira em torno desse reflexo mútuo entre passado, presente e futuro instaurado pelos devires. Instituições trabalhadas no texto, como a prisão, a lei e a justiça, são dispositivos com os quais o escritor se depara insistentemente em sua recriação do passado. O embate do menino com tais forças faz eco com a experiência carcerária na vida adulta, e é comum encontrarmos no livro passagens como essa:

Vivíamos numa prisão, mal adivinhando o que havia na rua, enevoada longos meses. Conhecíamos o beco: da janela do armazém, trepando em rolos de arame, víamos, em dias de sol, matutos de saco no ombro, cavalos amarrados num poste grosso, transeuntes que se chegavam cautelosos ao muro, espiavam os arredores e se afastavam depois de molhar o tijolo vermelho. ${ }^{46}$

Já em Memórias do cárcere, lemos o seguinte trecho:

Amanhecia. Uma das paredes laterais do galpão fechava-se, inteiriça; havia na outra janelas altas, inatingíveis. Por uma larga porta víamos, através das barras, as cercas de arame. [...] Chamaram-me a atenção forquilhas de numerosas pontas, arbustos secos feitos cabides, onde se

\footnotetext{
${ }^{45}$ Gilles Deleuze e Félix Guattari, Mil Platôs, vol. 2, 2012, p. 74.

${ }^{46}$ Graciliano Ramos, Infância, 2002, p. 55.
} 
penduravam canecos de lata, formando cachos barulhentos. Homens de zebra mexiam neles, distribuíam rápidos vasilhas nas mesas. ${ }^{47}$

Há nas duas passagens uma certa semelhança no que tange à perspectiva. O olhar do menino, alheio, distante, a observar o mundo com curiosidade, se mistura a um outro olhar, que busca nos detalhes as marcas de sua impotência diante de um agenciamento opressor, territorializado, repleto de linhas duras. Os canecos de lata, as cercas de arame, os homens de zebra são peças desse agenciamento tanto quanto os matutos de saco no ombro, os cavalos amarrados, a vista além do muro. Em ambos os trechos, menino e homem se fazem presentes na mesma medida; presente, passado e futuro são espectros de uma mesma realidade. Talvez o que a crítica de modo geral não conseguiu compreender é que, mais que uma volta ao passado sob o olhar crítico do adulto, Infância é uma busca pela percepção da criança. O escritor já no fim da vida encontra no devir criança uma nova potência criativa: "uma criança que secou consegue fazer-se de criança melhor ainda porque não emana mais dela qualquer fluxo de infância" ${ }^{48}$.

O devir não tem ponto de partida nem de chegada, ele se dá sempre "pelo meio". Isso quer dizer que não é a ligação entre dois pontos distantes (homem e criança) nem a contiguidade desses pontos que institui o devir, mas sim o traçar de uma linha sem começo e sem fim. O devir é um percurso sem origem e sem destino. "Um devir não é um nem dois, nem relação de dois, mas entre dois, fronteira ou linha de fuga, de queda, perpendicular aos dois" ${ }^{49}$. 0 devir é um bloco ao invés de um ponto, ele existe em uma zona de vizinhança, uma fronteira que

\footnotetext{
${ }^{47}$ Graciliano Ramos, Memórias do Cárcere, 2011, p. 430.

${ }^{48}$ Gilles Deleuze e Félix Guattari, Mil Platôs, vol. 4, 2012, p. 71-72.

${ }^{49}$ Ibidem, p. 97.
} 
demarca cada elemento ao mesmo tempo em que os torna indiscerníveis. Dessa forma, "o devir é uma antimemória"50, como o aprendizado por signos proustiano. Sua composição rizomática se opõe à arborescência da lembrança que remete à origem, à reterritorialização em uma genealogia, em um trauma etc. Em um devir, não se opera por lembranças, "mas por blocos, blocos de idades, blocos de épocas, blocos de reinos, blocos de sexos, formando igualmente devires entre as coisas, ou linhas de desterritorialização" ${ }^{51}$. Por isso Graciliano escreve Infância em blocos, capítulos que são como contos. Não há linearidade em seus relatos, eles atravessam diversos momentos diferentes da infância. As referências históricas são esparsas e quando aparecem é justamente para demonstrar seu caráter rizomático:

Fatos antigos se renovavam, confundiam-se com outros recentes, e as notícias dos jornais determinavam perturbações nos espíritos. Debatiamse Canudos, a Revolta da Armada, a Abolição e a Guerra do Paraguai como acontecimentos simultâneos. A república, no fim do segundo quadriênio, ainda não parecia definitivamente proclamada. ${ }^{52}$

A antimemória (ou devir) coletiva funciona da mesma maneira que a individual. Desloca-se de acontecimentos pretéritos a fatos recentes, sofrendo abalos provocados por outros, reescrevendo-se a todo instante. Não queremos dizer com isso que o devir não atravesse pontos fixos que o retraiam, já que toda desterritorialização inclui também movimentos de reterritorialização. A história em si é um vetor que tende a paralisar o devir, reduzindo suas linhas a pontos

\footnotetext{
${ }^{50}$ Ibidem, p. 98.

${ }^{51}$ Ibidem, p. 98.

${ }^{52}$ Graciliano Ramos, Infância, 2002, p. 47.
} 
localizáveis e coordenadas dentro de um sistema arborescente e memorial. Mas a função da arte é justamente implodir os sistemas pontuais, usando-os contra si mesmos: "um sistema pontual será mais interessante à medida que um músico, um pintor, um escritor, um filósofo se oponha a ele, e até o fabrique para opor-se a ele, como um trampolim para saltar" ${ }^{\prime 23}$. Graciliano sabe as dificuldades que enfrenta ao se propor recriar por meio da história. Há sempre o risco do sonho, do escapismo que cega, e também a armadilha de um excesso de realidade que pode vir a subjugar toda criação. Nas Memórias do cárcere, lemos:

\begin{abstract}
Uma frase repetida, que se despojara de significação, martelava-me: o estado guerra ia ser prorrogado. Isto me aborrecia. Para o diabo o estado de guerra. Imaginei-me em país distante, falando língua exótica, ocupando-me em coisas úteis, terra onde não só os patifes mandassem. Logo me fatiguei dessas divagações malucas e dei um salto para trás, vi-me pequeno, a correr num pátio branco de fazenda sertaneja, a subir na porteira do curral, a ouvir os bodes bodejarem no chiqueiro. De qualquer forma, enveredando no futuro ou mergulhando no passado, era um sujeito morto. Necessário esquecer tudo aquilo: o porão, o carro de segunda classe, o tintureiro, os cubículos, a recordação da infância, o país distante e absurdo, refúgio impossível. ${ }^{54}$
\end{abstract}

Ao ser levado em direção ao suplício na Ilha Grande, um futuro virtual surge no horizonte ao mesmo tempo em que do passado emergem recordações da infância. No entanto, tais deslocamentos não permitem ao sujeito escapar ao presente hediondo - "era um sujeito morto". Enquanto sonho ou evasão, a imaginação e a memória são inúteis. Necessário traçar linhas de fuga, mas de outra natureza: “é sempre sobre uma linha de fuga que se cria, não, é claro,

\footnotetext{
${ }^{53}$ Gilles Deleuze e Félix Guattari, Mil Platôs, vol 4., 2012, p. 99.

${ }^{54}$ Graciliano Ramos, Memórias do Cárcere, 2011, p. 404.
} 
porque se imagina ou se sonha, mas, ao contrário, porque se traça algo real, e compõe-se um plano de consistência. Fugir, mas fugindo, procurar uma arma"55. As verdadeiras linhas de fuga serão traçadas na escrita, é a partir dela que o passado, o presente e o futuro vão constituir a máquina de guerra contra o sistema elaborada por Graciliano Ramos. Resistir é característica intrínseca ao devir. Devir é se multiplicar. Não é mais um sujeito quem fala, mas todo um conjunto social, político e histórico. Tratando das mazelas educacionais nordestinas e brasileiras, Graciliano fala pelas crianças em formação por um sistema torpe, mas também pelos presidiários e resistentes à ditadura Vargas. Agenciamento coletivo de enunciação, as memórias de Graciliano Ramos são memórias do mundo.

\begin{abstract}
Em que sentido o enunciado é sempre coletivo, mesmo quando ele parece emitido por uma singularidade solitária como aquela do artista? É que o enunciado não remete jamais a um sujeito. Ele não remete mais a uma dupla, ou seja, a dois sujeitos dos quais um agiria como causa ou sujeito de enunciação, e o outro como função ou sujeito de enunciado. Não há um sujeito que emite o enunciado, nem um sujeito cujo enunciado seria emitido. [...] Mas de qualquer maneira que esta relação seja concebida, não acreditamos que o enunciado possa ser reportado a um sujeito, duplicado ou não, clivado ou não, refletido ou não [...]. Ora, quando um enunciado é produzido por um Celibatário ou uma singularidade artística, ele só o é em função de uma comunidade nacional, política e social, mesmo se as condições objetivas dessa comunidade não estão ainda dadas no momento fora da enunciação literária. ${ }^{56}$
\end{abstract}

De certa forma, Infância e Memórias do cárcere são duas faces de uma mesma moeda. Os dois livros de memórias são escritos de resistência contra

\footnotetext{
${ }^{55}$ Gilles Deleuze e Claire Parnet, Diálogos, 1998, p. 158.

${ }^{56}$ Gilles Deleuze e Félix Guattari, Kafka: Por uma literatura menor, 2014, p. 150-151.
} 
estruturas de poder que definem a sociedade brasileira, são componentes do agenciamento produzido por Graciliano, sua máquina de guerra contra o Aparelho de Estado que representa a ditadura Vargas e o coronelismo nordestino. Essa máquina de guerra também inclui a filiação do escritor ao Partido Comunista, suas atuações políticas. Nesse ponto, o leitor poderia intervir: 'Mas então vocês remetem novamente a obra de Graciliano à sua biografia'. Respondemos: sim, mas não da maneira tradicional. A vida atravessa e mesmo produz a arte, mas esta não se resume a representar a primeira. "Viver e escrever, a arte e a vida, só se opõem do ponto de vista de uma literatura maior"57. Em uma literatura menor, vida e arte são sinônimos. Portanto, no agenciamento literário Graciliano Ramos, há mais que um projeto ético e estético: há um projeto de vida.

Em Graciliano, há um desejo de memória, uma vontade de se lembrar que não se confunde com o ressentimento. Graciliano não rememora sua experiência seguindo o imperativo da dor e do sofrimento, como quiseram vários de seus críticos; a memória de Graciliano é a memória de Nietzsche, como lida por Deleuze, é memória afirmativa: lembrar-se porque se quer lembrar. Essa é a memória da vontade, a memória do desejo. Um desejo de se lembrar e escrever por quem não tem lugar nem voz na história oficial. “As memórias têm esse caráter luminoso de resgate criador de uma experiência compartilhada em meio às trevas, de conjunção solidária da mão que desenha a letra miúda no papel amassado com outras mãos, inaptas ao trato da palavra escrita que resguarda e transforma o vivido" 58 . Graciliano supera o memorialismo como monumento de si por meio da criação de linhas de fuga que escapam à história oficial.

\footnotetext{
${ }^{57}$ Ibidem, p. 77.

${ }^{58}$ Wander Melo Miranda, Corpos escritos, 2009, p. 17.
} 
Esgueirando-se pelos cantos, como o próprio escritor diz, ele se mostra intempestivo e traz à tona uma realidade outra, em que os excluídos da história oficial assumem o protagonismo. Esses por quem o escritor fala não existem aos olhos do poder; embora possam estar incluídos como cidadãos em uma nação chamada Brasil, não há (e nunca haverá) uma comunidade constituída por eles. Não se trata aqui de se colocar como "representante" de um povo excluído, mas de escrever por, não em lugar de, mas em intenção de, um povo que falta, pois, ser parte de um povo é sempre estar em processo, em uma linha de fuga sempre desviante. É essa falta, essa fuga permanente à própria potência que move a literatura, ela só existe em apelo a essa comunidade por vir. Escrever por esse povo que falta é a tarefa da qual se incumbe Graciliano Ramos.

\section{Referências}

BRAYNER, Sônia (Org.). Fortuna crítica. Rio de Janeiro: Civilização Brasileira, 1978.

BULHÕES, Marcelo Magalhães. Literatura em campo minado: a metalinguagem em

Graciliano Ramos e a tradição literária brasileira. São Paulo: Annablume; 1999.

CANDIDO, Antônio. Ficção e confissão: ensaios sobre Graciliano Ramos. Rio de Janeiro: Ouro sobre azul, 2012.

DELEUZE, Gilles. Crítica e clínica. Trad. Peter Pál Pelbart. São Paulo: Ed. 34, 2011.

DELEUZE, Gilles. Proust e os signos. Trad. Antônio Piquet e Roberto Machado. Rio de Janeiro: Forense universitária, 2010. 
DELEUZE, Gilles; GUATTARI, Félix. O anti-Édipo: capitalismo e esquizofrenia.

Trad. Luiz B. L. Orlandi. São Paulo: Ed. 34, 2010.

DELEUZE, Gilles; GUATTARI, Félix. Kafka: por uma literatura menor. Trad. Cíntia Vieira da Silva. Belo Horizonte: Autêntica, 2014.

DELEUZE, Gilles; GUATTARI, Félix. Mil Platôs: Capitalismo e Esquizofrenia 2, vol. 2. Trad. Ana Lúcia de Oliveira e Lúcia Cláudia Leão. São Paulo: Ed. 34, 2011.

DELEUZE, Gilles; GUATTARI, Félix. Mil Platôs: Capitalismo e Esquizofrenia 2, vol. 4. Trad. Suely Rolnik. São Paulo: Ed. 34, 2012.

DELEUZE, Gilles; GUATTARI, Félix. O que é a Filosofia? Trad. Bento Prado Jr. e Alberto Alonso Muñoz. São Paulo: Ed. 34, 2010.

DELEUZE, Gilles, PARNET, Claire. Diálogos. Trad. Eloísa Araújo Ribeiro. São Paulo: Ed. Escuta, 1998.

GARBUGLIO, José Carlos; BOSI, Alfredo; FACIOLI, Valentim. Antologia \& Estudos: Graciliano Ramos. São Paulo, Ática, 1987.

LINS, Álvaro. Valores e misérias de Vidas Secas. In: RAMOS, Graciliano. Vidas Secas. Rio, São Paulo: Record, 2002.

MIRANDA, Wander Melo. Corpos Escritos. São Paulo: Editora da Universidade de São Paulo, 2009.

MIRANDA, Wander Melo. Graciliano Ramos. São Paulo, Publifolha, 2004. (Folha explica). 
OLIVEIRA, Maria de Lourdes. Cacos da memória: uma leitura de "Infância", de

Graciliano Ramos. Dissertação de Mestrado. Belo Horizonte: FALE/UFMG, 1992.

RAMOS, Graciliano. Cartas. Rio, São Paulo: Record, 1994.

RAMOS, Graciliano. Infância. Rio, São Paulo: Record, 2002.

RAMOS, Graciliano. Linhas Tortas. Rio, São Paulo: Record, 2002.

RAMOS, Graciliano. Memórias do Cárcere. Rio de Janeiro: Record, 2011.

RIBEIRO, Gustavo Silveira. Abertura entre as nuvens. São Paulo: Annablume, $2012 \mathrm{a}$

SENNA, Homero. República das letras: entrevistas com 20 grandes escritores brasileiros. Rio de Janeiro: Civilização Brasileira, 1996.

\section{Referência para citação deste artigo}

SOUZA, Bruno Henrique Alvarenga. O devir-criança de Graciliano Ramos: uma leitura de Infância a partir de Deleuze. Revista PHILIA | Filosofia, Literatura \& Arte, Porto Alegre, volume 2, número 1,p. 144 - 174, junho de 